\title{
Monitoring Domoic Acid in Marine Phytoplankton by Disposable Immunosensors
}

\author{
Roberta Congestri ${ }^{1}$, Laura Micheli $^{2,3^{*}}$, Giuseppe Palleschi ${ }^{2,3}$ \\ ${ }^{1}$ Laboratory of Biology of Algae, Department of Biology, University of Rome “Tor Vergata”-Via Cracovia 1, Rome, Italy \\ ${ }^{2}$ Department of Chemical Sciences and Technologies, University of Rome "Tor Vergata"-Via della Ricerca Scientifica, Rome, Italy \\ ${ }^{3}$ Consorzio Interuniversitario Biostrutture e Biosistemi “INBB”, Viale Medaglie d'Oro 305, Rome, Italy \\ Email: ^laura.micheli@uniroma2.it
}

How to cite this paper: Congestri, R., Micheli, L. and Palleschi, G. (2017) Monitoring Domoic Acid in Marine Phytoplankton by Disposable Immunosensors. American Journal of Plant Sciences, 8, 1077-1091. https://doi.org/10.4236/ajps.2017.85071

Received: March 14, 2017

Accepted: April 23, 2017

Published: April 26, 2017

Copyright (c) 2017 by authors and Scientific Research Publishing Inc. This work is licensed under the Creative Commons Attribution International License (CC BY 4.0).

http://creativecommons.org/licenses/by/4.0/ (c) (i) Open Access

\begin{abstract}
Advances in sensor technology have allowed the significant progress in the monitoring of noxious compounds in the sea, providing real-time detection so as to prevent risks associated with the diffusion and dispersion of toxic substances in the environment. An important element in the overall picture is the harmful algal blooms which pose serious threats to marine ecosystems through the production of toxins that accumulate in filter-feeders and ultimately impact both human health and fisheries. Domoic acid is a neurotoxic amino acid produced by marine planktonic diatoms of the genus Pseudo-nitzschia. Here we monitored domoic acid production by natural Pseudo-nitzschia populations in phytoplankton samples collected along the Middle Tyrrhenian coast, over the course of one year, using selective immunosensors based on screenprinted electrodes, using differential pulse voltammetry as the electrochemical technique, to yield quantitative outputs. In this work, disposable devices have been applied for monitoring the production of domoic acid on algal extracts and the results have been validated by conventional high pressure liquid chromatography-ultraviolet detection methods. The data obtained revealed the presence of domoic acid in Italian phytoplankton, especially in coastal impacted areas, highlighting the potential risk of toxin entering into marine food webs and the environment. Immunosensors based on screen-printed electrodes prove to be effective tools for annual monitoring of domoic acid in seawater samples, thus providing a reliable early warning system relative to health and economic impact of algal toxins.
\end{abstract}

\section{Keywords}

Domoic Acid Monitoring, Immunosensors, Screen Printed Electrodes, Toxic Pseudo-nitzschia 


\section{Introduction}

Harmful Algal Blooms (HABs) are an important environmental and public health problem all over the world and their economic impact can produce losses of great magnitude in the affected areas [1] [2]. HABs have been increasingly frequent, in recent years, endangering marine coastal life and food resources through massive growth of microalgae [3] [4]. Some HAB species produce toxins that may accumulate beyond the defined safety level in filter-feeders ultimately causing acute or chronic syndromes in humans. Marine biotoxins can also directly bring about animal mortalities, causing extensive seafood mortalities and seafood market closures involving the contaminated products [5] [6].

The marine biotoxin domoic acid (DA) is an analogue of the excitatory amino acid glutamate and acts as a neurotoxin in animals. DA is primarily produced by planktonic diatoms belonging to the cosmopolitan genus Pseudo-nitzschia. During Pseudo-nitzschia blooms, DA can contaminate shellfish and other filter feeders and can be transferred by ingestion to higher trophic levels that include marine mammals, seabirds and humans, causing the neurologic syndrome known as Amnesic Shellfish Poisoning (ASP) [7] [8] [9].

Blooms of Pseudo-nitzschia are recurrent phenomena in Italian coastal waters, with densities reaching up to $10^{6}$ cell/L for prolonged periods of time and exceeding the regulatory level of $10^{5}$ cell/L [10] [11] [12]. Ultrastructural examination of natural phytoplankton samples highlighted mass densities of at least six potentially toxic species in the Middle Tyrrhenian Sea (Mediterranean Sea) [12] and toxicity had been proven in cultures of Pseudo-nitzschia galaxiae and $P$. multistriata strains isolated from the Gulf of Naples [13] [14]. However, potentially toxic Pseudo-nitzschia species appear more widespread than the toxicity events in the whole Mediterranean basin, which indicates there is a high risk that toxicity may suddenly arise in some areas as a consequence of the increased exploitation of marine resources.

Following the first documented ASP event in Canada [15], the European Commission Directive 2002/226/EC implemented a maximum permitted level (MPL) of $20 \mathrm{mg}$ of domoic acid/kg in whole shellfish intended for human consumption [16]. High performance liquid chromatography with ultraviolet detection (HPLCUV) is the first chemical analytical method employed for DA detection and is still the most commonly used for monitoring shellfish [17]. The HPLC-UV method has been validated and standardised through the AOAC International Official Methods Program (AOAC method 991.26 and European Committee for Standardization (CEN) method 14176) [18]. Several other chemical methods have been developed to improve analytical sensitivity [19] and include liquid chromatography-mass spectrometry using reaction monitoring (MRM) [20]. Although these techniques provide good accuracy and reproducibility, several drawbacks remain: they require time-consuming sample preparation and the Electrospray Ionization (ESI) interface of the mass spectrometry turns out to be susceptible to salt effects with a decrease in instrumental sensitivity and dynamic range [21]. Thus, procedures based on HPLC combined with ultraviolet diode array detec- 
tion (UV-DAD), ESI or MS appear suitable for laboratory assays and confirmatory investigations. However, due to the increasing exploitation of marine coastal resources high throughput screening and/or on-site testing would be more desirable but the standard laboratory instrumentation is often inadequate for such operation as it is expensive, time consuming and not portable. In addition, a method based on enzyme-linked immunosorbent assay (ELISA) has been validated (AOAC method 2006.02) and is officially allowed to be used in the EU for screening purposes [16]. The assay is primarily intended for using in routine monitoring of DA levels in bivalve molluscs to comply with the regulatory MPL, but is also applicable for DA quantification in other marine matrices like algal samples, seawater and body fluids of marine mammals.

Recently ELISA assays have been coupled with screen-printed electrodes (SPEs) to assemble disposable immunosensors for simple and fast measurement of several types of analytes (pesticides, toxins, heavy metals and hormones) found in the environment and food [22]-[29]. These systems combine the selectivity and sensitivity of immunological assays with a short analytical time and can be inexpensively produced in a "ready to use" form for field analysis by means of a portable electrochemical detector. However, few immunosensors are commercially available at present and they have yet to be established as research or routine tools, due to the lack of validated protocols for a wide range of sample matrices.

In this study, we have directly applied a detection method based on a disposable immunosensor coupled to a highly sensitive electrochemical technique, previously developed for DA determination in mussels [22], to marine phytoplankton samples. The developed immunosensor required assay procedure optimization for application to the phytoplankton matrices. The method basically involves the use of screen-printed electrodes (SPEs) with an "indirect competitive ELISA format" and the differential pulse voltammetry (DPV) for toxin detection. To our knowledge, this is the first study to determine DA in natural microalgal samples collected from Italian coastal waters over an annual cycle. Results indicate the potential of this SPEs-based method for monitoring DA at critical sites and during particular times of the year in order to provide an early warning of toxin presence in seawater phytoplankton and thus to prevent poisoning of humans and other animals.

\section{Materials and Methods}

\subsection{Chemical and Reagents}

DACS-1C certified calibration solution $(100 \mu \mathrm{g} \mathrm{DA} / \mathrm{mL})$ was obtained from the Canadian National Research Council (http://www.nrc-cnrc.gc.ca/, Halifax, Canada). Affinity purified anti-goat $\operatorname{IgG}(\mathrm{H}+\mathrm{L}$, from mouse), alkaline phosphatase conjugate $\left(\mathrm{Ab}_{\mathrm{II}}-\mathrm{AP}\right)$, polyvinyl alcohol (PVA) and all other reagents were from Sigma (www.sigma-aldrich.com, St Louis, MO, USA). 1-naphthyl phosphate (1NPP) was obtained from Fluka Chemie (www.sigma-aldrich.com, Sigma-Aldrich, Milan, Italy). Bovine serum albumin conjugated with DA (BSA-DA) and 
the polyclonal antibodies against $\mathrm{DA}\left(\mathrm{PAb}_{\mathrm{I}}\right.$ from sheep) were kindly provided by Toxicology and Food Safety Research (AgResearch Limited, www.agresearch.co.nz/, New Zealand). Domoic acid (DA), used to prepare the standards and the spiked samples, was from Biomol (www.enzolifesciences.com/, Plymouth Meeting, USA). Single use syringe filters were purchased from Sartorius AG (www.sartorius.it, Bagno a Ripoli, Italy).

\subsection{Apparatus}

All electrochemical measurements were performed using a computer-controlled system, AUTOLAB model PGSTAT 12 with GPES software (ECO-CHEMIE, The Netherlands). The screen-printed electrodes (SPEs) were produced with a 245 DEK (Weymouth, UK) screen printing machine. Graphite based ink (Electrodag 423 SS) from Acheson (Milan, Italy) was used to print the working and counter electrode. Silver ink (Electrodag 477 SS) was used to print the reference electrode. The substrate was a flexible polyester film (Autostat HT5) obtained from Autotype Italia (Milan, Italy). The electrodes were home produced in foils of 48 . The diameter of the working electrode was $0.3 \mathrm{~cm}$ resulting in a geometric area of $0.07 \mathrm{~cm}^{2}$.

The HPLC system consisted of a modular Chromoquest spectral system form Thermoquest (San Jose, CA, USA), equipped with two P4000 pumps, a Shimadzu UV-VIS spectrometer, model (SPD-10AV) as detector. An SN 4000 controller operated the HPLC system working under software HPLC CL VP 4.3 software. The chromatographic separation was performed using a reverse phase $\mathrm{C} 18$ RESTEK Pinnacle $\mathrm{II}^{\mathrm{Tm}} \mathrm{C} 18,(250 \times 4.6 \mathrm{~mm}$, D $3 \mu \mathrm{m})$ stainless steel column.

The Ultrasonic Cell Disruptor system was a SONIFER B12 (G. Heinemann, Germany).

\subsection{Procedure for Immunosensor Production}

The immunosensor for DA determination was realized as described by Micheli et al. [22] based on screen-printed electrodes (SPEs). Immunoassays were performed on the carbon-working surface of an SPE, which was modified in order to obtain a device to react with specificity and selectivity towards analyte.

The working electrode was coated with $7 \mu \mathrm{l}$ of $0.1 \mathrm{M}$ of $50 \mathrm{mM}$ carbonate buffer $\mathrm{pH} 9.6(\mathrm{CB})$, containing BSA-DA conjugate $(30 \mu \mathrm{g} / \mathrm{mL})$ and incubated for $1 \mathrm{~h}$ at room temperature. After washing with $160 \mu \mathrm{l}$ of $15 \mathrm{mM}$ phosphate saline buffer with Tween 20 (5\%) PBS-T ( $2 \mathrm{~min}$ ) and then $160 \mu \mathrm{l}$ of PBS (2 times, 2 $\mathrm{min}$ ), the electrode was treated with blocking reagent (1\% PVA in $\mathrm{CB}$ ) for 30 min at room temperature.

Competition reactions involved the addition a PBS-M solution with a fixed concentration of $\mathrm{PAb}_{\mathrm{I}}(1: 500 \mathrm{v} / \mathrm{v})$ and with various concentrations of DA standard for $30 \mathrm{~min}$ at room temperature. After the washing step, the $A b_{I I}-A P$ $(1: 1000 \mathrm{v} / \mathrm{v}, 6 \mu \mathrm{L})$ was incubated on the working electrode for $15 \mathrm{~min}$. After another washing step, the enzymatic reaction was performed by addition of the substrate solution $(80 \mu \mathrm{l})$ to each electrode. 
Differential pulse voltammetry (DPV) was used to measure the analytical signal (potential range $0-600 \mathrm{mV}$, scan rate $300 \mathrm{mV} / \mathrm{s}$, pulse amplitude $70 \mathrm{mV}$, pulse width $50 \mathrm{~ms}$ ). $80 \mu \mathrm{L}$ of solution containing the enzymatic substrate (1 $\mathrm{mgmL}^{-1} 1$-NPP in diethanolamine buffer, DEA, with $1 \mathrm{mM} \mathrm{MgCl}_{2}$ ) was applied on the sensor surface. After 2 min of incubation, the DPV measurement was started and the resulting current recorded.

\subsection{HPLC Analysis}

For immunosensor validation, separation and chromatographic analyses were performed according to the recommended instructions given in MUS-1 Certified Reference Material, Mussel Tissue Reference Material for Domoic Acid, NRC-CNRC [30]. The mobile phase was aqueous acetonitrile with $0.1 \%$ trifluoroacetic acid and a flow rate of $0.7 \mathrm{~mL} \cdot \mathrm{min}^{-1}$ (loop $20 \mu \mathrm{L}$ ) for $15 \mathrm{~min}$. Detection was accomplished by monitoring absorbance at $242 \mathrm{~nm}$ with a $10 \mathrm{~nm}$ bandwidth [19] [30]. Quantification of DA was obtained by comparing the areas of peaks from extracts with those from a dilution series of the DACS- 1 calibration solution. The calibration curve for DA was linear over 3 orders of magnitude and reproducibility of this external calibration procedure was 3\% RSD for 6 repeated analysis of a single extract.

\subsection{Sampling and Sample Preparations}

Samples were collected fortnightly, when possible, at 6 stations, $500 \mathrm{~m}$ offshore, along the Latium coast, in a $300 \mathrm{~km}$ stretch (Middle Tyrrhenian Sea), from January 2001 to December 2002 (Foce Marta, VTA; Ladispoli, RMB; Fiumicino, RMC; Rio Martino, LTD; Monte d'Argento LTE; Zannone Island, LTF, Figure 1) in the framework of a research collaboration between the University of Rome "Tor Vergata" and the Regional Agency for Environmental Protection of Latium (ARPAlazio) on coastal environment assessment and algal surveillance activities [Programma di Monitoraggio per il Controllo dell'Ambiente Marino Costiero (L. 979/82), Programma di Sorveglianza Algale (D.P.R. 470/82) from 1998]. Closing plankton net (mouth diameter of $0.21 \mathrm{~m}$ and $20 \mu \mathrm{m}$ mesh size) was towed obliquely for $300 \mathrm{~m}$ intervals to obtain concentrated phytoplankton samples. After gentle mixing to homogenize the suspension, each sample was subdivided into two aliquots. A $5 \mathrm{~mL}$ aliquot was immediately preserved with $2.5 \%$ glutharaldehyde for electron microscopy to confirm species identification [12]. A second aliquot (50 to $200 \mathrm{~mL}$ suspension) was concentrated, within $48 \mathrm{~h}$ from collection, onto a $5.0 \mu \mathrm{m}$ membrane filter. The filters were then transferred to a graduated tube and stored at $-20^{\circ} \mathrm{C}$ for DA determination according to Bates et al. [31].

For DA measurements, a fixed volume $(5.2 \mathrm{~mL})$ of $\mathrm{CH}_{3} \mathrm{OH}: \mathrm{H}_{2} \mathrm{O}(3: 1 \mathrm{v} / \mathrm{v})$ solution was added to membrane filters. Filters, after mixing ( $1 \mathrm{~min}$ ), were sonicated for $2 \mathrm{~min}$ at $28 \mu$ s amplitude and the suspension then centrifuged at 3000 rpm (10 $\mathrm{min})$ to remove the particulate. Then, the supernatant was filtered through a $0.22 \mu \mathrm{m}$ filter and analyzed, without dilution, by immunosensor and 


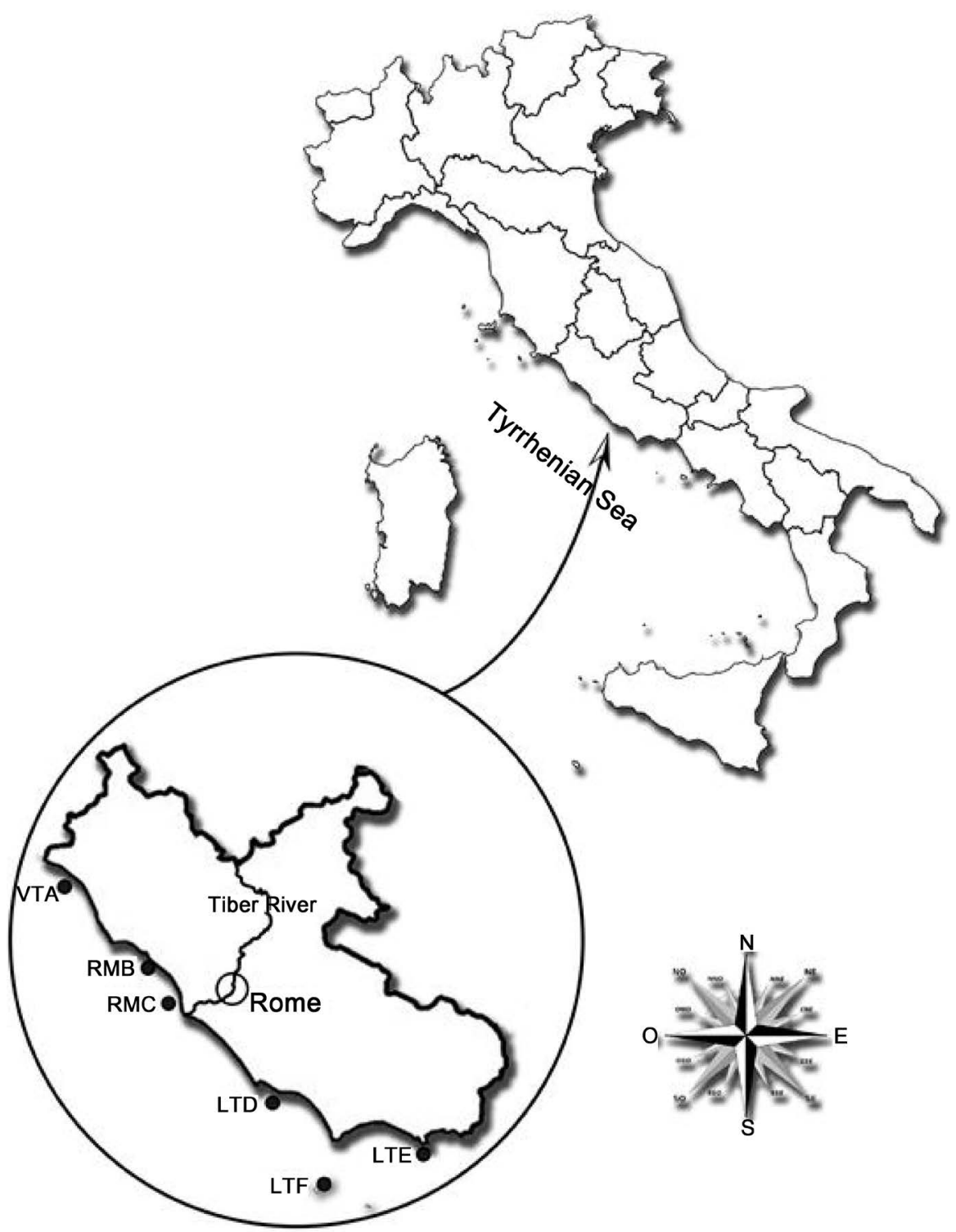

Figure 1. Study area along the Middle Tyrrhenian coast and sampling sites in the inset.

by HPLC methods following Micheli et al. [22] and the procedure reported in [19] [30].

\subsection{Determination of Recovery}

DA recovery from phytoplankton was determined by adding DACS-1 followed by $1 \mathrm{~mL}$ of sonicated phytoplankton samples with no Pseudo-nitzschia present (after microscopy measurements) and domoic acid (determined by HPLC measurements)to a $13 \mathrm{~mm} \times 100 \mathrm{~mm}$ disposable screw-cap glass test tube at $3 \mathrm{DA}$ concentrations $\left(0.5,20,60 \mathrm{ng} \cdot \mathrm{mL}^{-1}\right)$, each in triplicate. The spiked samples were concentrated on membrane filters and stored at $-20^{\circ} \mathrm{C}$ according to the procedure described above.

The analysis of each spiked sample was repeated five times in the same day to obtain repetitively values and five times on three different days to obtain repeat- 
ability values. Confirmation of the immunosensor results was obtained by analyzing the same extracts (sample or spiked phytoplankton) using a previously validated HPLC method [19] [30].

\subsection{Calibration Plots and Analysis of Samples}

Standard curves were obtained using DA standard solutions prepared in $15 \mathrm{mM}$ phosphate saline buffer (PBS), $\mathrm{pH} 7.4$, with $10 \% \mathrm{CH}_{3} \mathrm{OH}$ (PBS-M) in the range 0

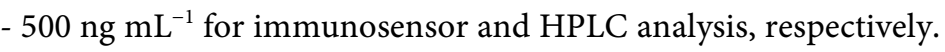

The data obtained for each curve (measured current versus competitor concentration) for the immunosensors were fitted using a "non-linear 4 parameter logistic calibration plots" [32] and Sigma Plot software (SPSS). The four parameter logistic function (Equation (1)) is:

$$
f(x)=\left\{[1-a] /\left[1+(x / c)^{b}\right]\right\}+d
$$

the parameters " $a$ " and “ $d$ " are the asymptotic maximum and minimum values, respectively; " $c$ " is the value at the inflection point $\left(\mathrm{IC}_{50}\right)$ and $b$ is the slope. The detection limit (LOD) was defined as the decrease of the maximum signal equal to three times the value of the standard deviations $\left(I_{0}-3 \mathrm{SDs}\right)$, measured in the absence of DA ( $\mathrm{I}_{0}$, no competition point). Before analysing samples, the matrix effect was evaluated using phytoplankton samples with no Pseudo-nitzschia present (after microscopy observations) and domoic acid (HPLC analysis), called "blank samples" from now on in the text. The matrix effect on immunosensor measurements was evaluated by comparison of the two calibration curves realised with the same known amount of DA standard: the first was obtained with DA standard prepared in PBS-M (assay buffer); the second in blank samples spiked with the same amount of DA standard used for the first curve.

\section{Results and Discussion}

A total of 105 phytoplankton samples were collected and aliquots immediately observed by light microscopy for a phytoplankton survey. Subsamples for DA analysis were filtered and stored without any washing or other treatment (as described in the experimental section).

Before analyzing samples collected on filters (particulate DA), the effect of this matrix on the immunosensor analysis was evaluated using two spiked blank samples with the same concentration of DA standard utilised for calibration curves in buffer. The standard curve for DA diluted in PBS-M (•, Figure 2) was constructed and compared with the calibration curves obtained in spiked blank samples (see material and methods) ( $\triangle$ and $\times$, Figure 2 ). The linear regression of the calibration curves obtained in buffer (PBS-M; Y $=167.80-90.58 \mathrm{X}, \mathrm{r}^{2}=$ $0.972)$ and in both algal blank samples $\left(\mathrm{Y}_{1}=162.25-86.20 \mathrm{X}, \mathrm{r}^{2}=0.979 ; \mathrm{Y}_{2}=\right.$ $\left.161.11-85.38 \mathrm{X}, \mathrm{r}^{2}=0.979\right)$ showed comparable slopes, indicating that there was no significant matrix effect by the various components present in phytoplankton samples on electrochemical measurements. The slope of the linear regression of the three calibration curves were similar, but not equal indicating that the 


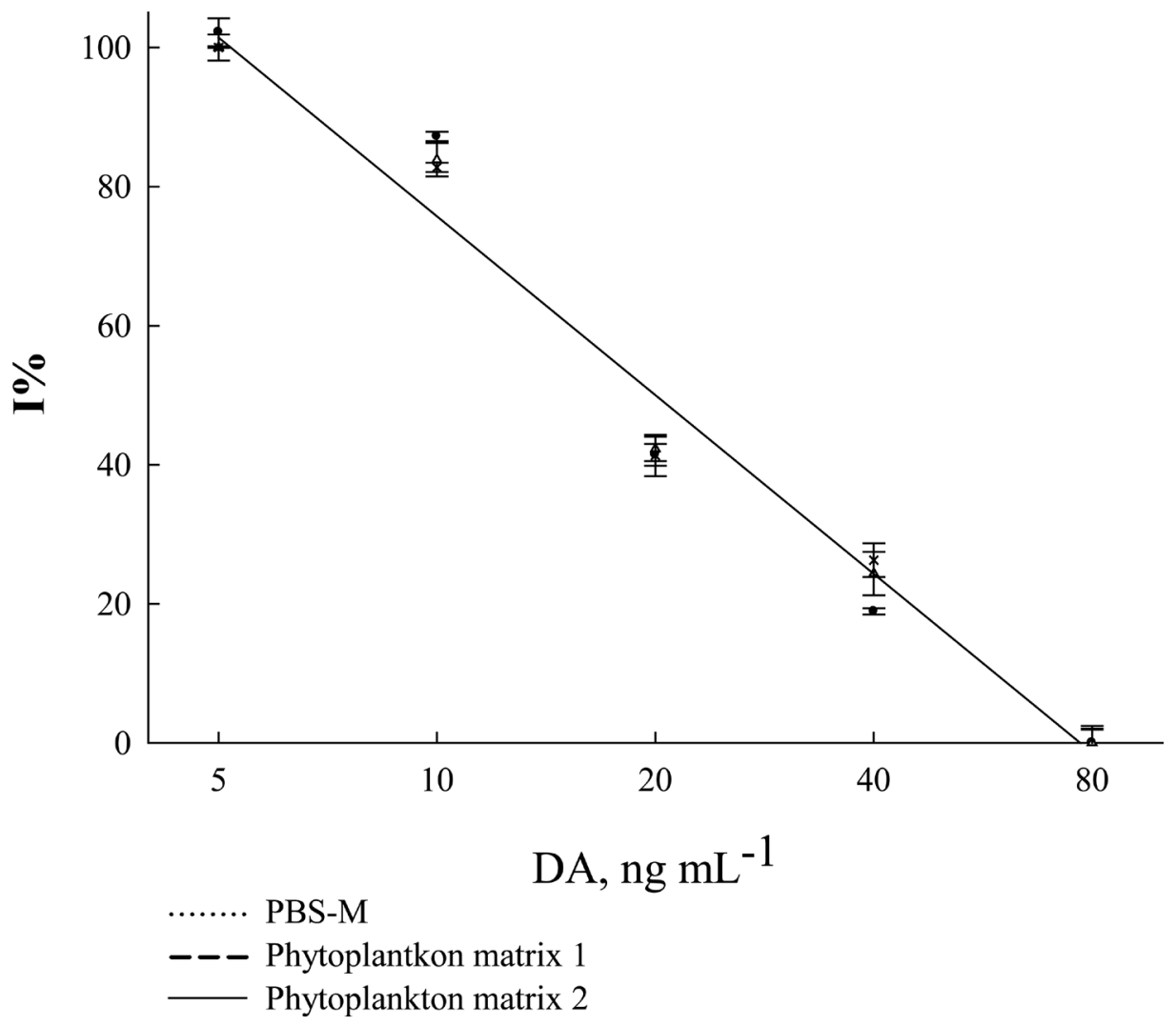

Figure 2. Study of matrix effect: comparison of calibration curves for DA obtained in buffer (saline phosphate buffer-methanol; PBS-M) $(\bullet)$, and in two blank algal matrixes of the matrix $(\triangle$ and $\mathrm{x})$.

sensitivity of the analysis (determined by the slope) was not significantly affected by the sample matrix. This effect is very little, as can be observed by the linear regression lines that are superimposed for the two matrices, and parallel but not coincident with that in buffer, probably due to the different composition (ionic strength and matrix components) of the matrix from the algal buffer.

In all cases, the linear range and detection limit (LOD) were, respectively, between 5 and $80 \mathrm{ng} \cdot \mathrm{mL}^{-1}$ and around $1 \mathrm{ng} \cdot \mathrm{mL}^{-1}$. Precision assays were carried out at three levels $\left(5,20,60 \mathrm{ng} \cdot \mathrm{mL}^{-1}\right)$ and the results were satisfactory. The RSD\% values $(\mathrm{n}=5)$ obtained ranged from $2 \%$ to $6 \%$ for repeatability (intra-day precision) and from $2 \%$ to $4 \%$ for intermediate (inter-day) precision. The intra-electrode reproducibility, expressed as \%RSD, was of $6.6 \%$, for a concentration of 10 $\mathrm{ng} \cdot \mathrm{mL}^{-1}$ with $\mathrm{n}=30$.

Recovery studies were carried out using validation samples collected on the same membrane filters as the ones used for phytoplankton analysis, in order to evaluate the accuracy of the method. Samples were spiked (artificially contaminated phytoplankton) with DA concentrations equal to $5,20,60 \mathrm{ng} \cdot \mathrm{mL}^{-1}$ before the extraction. Due to the lack of toxin limit for phytoplankton samples, we decided to validate results using the three concentration levels comprised in the immunosensor linear range. Confirmation of the immunosensor results for spiked samples was obtained analyzing the same extracts by the HPLC method 
Table 1. Study of the recovery and relationship with HPLC results.

\begin{tabular}{rrrrrrrr}
\hline Standard & \multicolumn{3}{c}{ Immunosensor } & \multicolumn{2}{c}{ HPLC } \\
\cline { 2 - 3 } $\begin{array}{r}\text { DA, } \\
\mu \mathrm{g} / \mathrm{mL}\end{array}$ & $\begin{array}{r}\text { DA } \\
\text { observed, } \\
\mu / \mathrm{mL}\end{array}$ & Recovery \% & RSD\%* $^{*}$ & $\begin{array}{r}\text { DA } \\
\text { observed, } \\
\mu / \mathrm{mL}\end{array}$ & Recovery \% & RSD\%* $^{*}$ & \\
\hline 5.0 & 4.9 & 98 & 8 & 4.9 & 98 & 2 & 0 \\
2.5 & 2.0 & 80 & 9 & 2.5 & 100 & 3 & -20 \\
0.5 & 0.4 & 80 & 8 & 0.6 & 120 & 2 & -30 \\
\hline
\end{tabular}

${ }^{*} \mathrm{RSD} \%$ (relative standard deviation\%) $=($ standard deviation $/$ media of concentration $) \times 100 ;{ }^{*} \mathrm{RE} \%$ $($ relative error\% $)=[($ measuredvalue - truevalue $) /$ truevalue $] \times 100$.

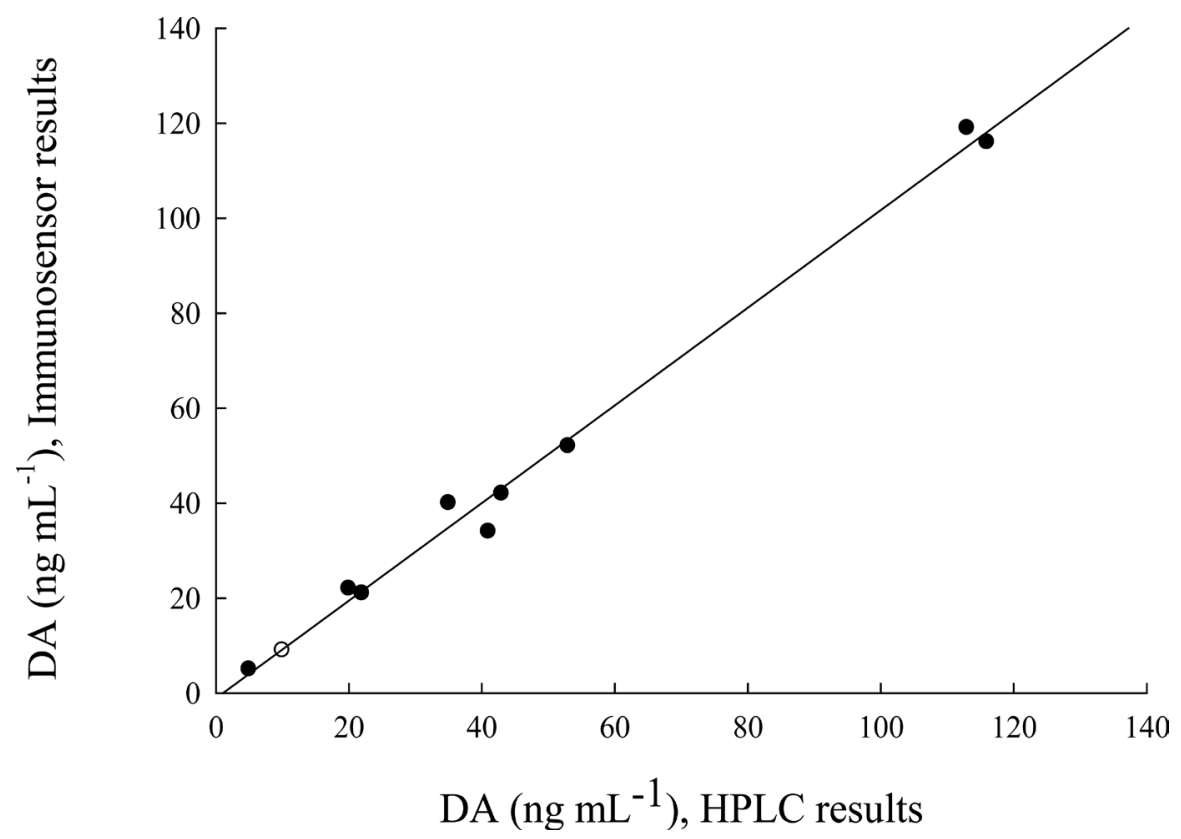

Figure 3. Comparison of the results obtained with immunosensor and HPLC in order to evaluate the accuracy of the proposed electrochemical immunosensor versus chromatographic analyses [18] using spiked phytoplankton samples (• correlation point).

following the AOAC protocol [17]. The recovery of DA ranged between $100 \%$ $80 \%$, with good agreement between the proposed and the conventional methods. Table 1 reports the accuracy of immunosensor versus HPLC analyses for artificially contaminated phytoplankton and evaluated resulting around $20 \%$.

After the evaluation of the proposed electrochemical results in algal matrix, phytoplankton samples were analyzed by the immunosensor method and the data validated by HPLC analyses (Figure 3: $\mathrm{Y}=1.03 \mathrm{X}-1.08$, for $\mathrm{n}=10$ ), obtaining a scatterplot satisfactory agreement $(R=0.993) .26$ samples were found to be positive using the immunosensors and 31 using HPLC (Figure 4, Table 2).

This is the first study to document the presence of DA and its concentration in natural phytoplankton samples from the Italian seawater. Although this toxin has been found in shellfish from the Adriatic Sea, on both Italian [33] and Croatian [34] coasts, as well as in cultured strains of the major representative Pseudonitzschia species from Italian waters, no previous research aimed at investigating 
Table 2. Comparison of the results, in terms of DA concentration found, obtained for the phytoplankton samples analysed by the immunosensor and HPLC.

\begin{tabular}{ccc}
\hline Immunosensor & HPLC & RE\% \\
\cline { 1 - 2 } DA found $(\mathrm{ng} / \mathrm{mL})$ & DA found $(\mathrm{ng} / \mathrm{mL})$ & -10 \\
\hline 9 & 10 & -17 \\
34 & 41 & 5 \\
119 & 113 & -5 \\
21 & 22 & -2 \\
42 & 43 & -2 \\
52 & 53 & -10 \\
22 & 20 & 0 \\
116 & 116 & 0 \\
5 & 5 & 14 \\
\hline 40 & 35 & \\
\hline
\end{tabular}

the temporal history (occurrence and seasonal variations) of DA directly in the potential producing organisms. In any case, there have not been any reported incidences of ASP in Italian waters. This highlights the fact that the presence or absence of DA contamination in local food webs may not reflect either the magnitude of the local population of toxic Pseudo-nitzschia or their local production of DA, as has also been hypothesized for some stretches of the Californian coast [35] [36], where most of the studies on DA in phytoplankton were carried out.

The results presented here document the particulate DA (pg DA L $\mathrm{L}^{-1}$ ), as evaluated using electrochemical immunsensors in phytoplankton samples from five coastal stations, known to be impacted, and in one control site. We also carried out parallel electron microscopic analyses of samples and assessed the Pseudo-nitzschia diversity therein. Results revealed the presence of at least eight different Pseudo-nitzschia species, 6 of which are known DA producers in culture [12].

DA concentration varied between the monitored stations, and in addition, intra-annual variability was observed at each single station. This highlighted certain periods and conditions that may influence both the potential impact over the year as well as variations along the sampled stretch of coast. In particular, the VTA and LTE stations showed the highest number of positive samples (seven out of 19 and 15, respectively), while samples from the control site, Zannone Island (LTF), revealed no presence of DA whereas at LTD only 2 winter records of DA, below $7 \mathrm{pg} \mathrm{L}^{-1}$, were detected (Figure 4). There was a distinct north-south differentiation between sampling sites in relation to frequency of DA detected, with the stations located to the north of the Tiber River mouth (VTA, RMB, RMC) showing higher numbers of positive results. The absolute maximum DA concentration in the extracts ( $7830 \mathrm{pg} \mathrm{DA} \mathrm{L}{ }^{-1}$ ) was registered at RMC in the late June sampling. It is very interesting to note that the maximal concentrations measured at the Italian stations studied were substantially lower (on average 


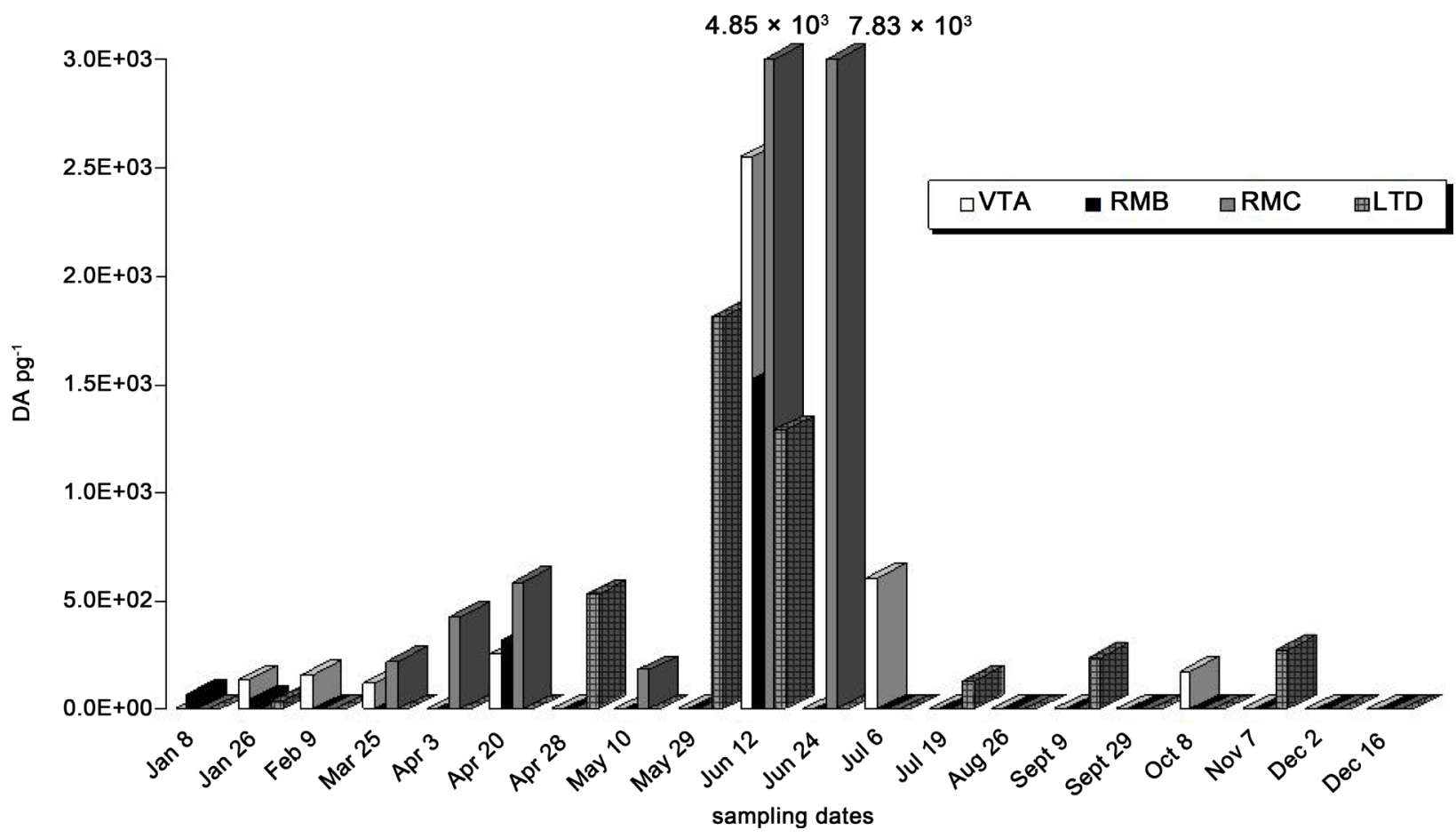

Figure 4. DA concentration in the samples, data (only two records) for station LTD are not shown.

500-fold) than values recorded during surveys conducted in Californian surface waters, from 1991 to 2007 [35] [36] and more recently in the Eastern English Channel (Normandy, France [37]). However, the DA levels recorded in our study were comparable to concentrations determined in natural plankton assemblages from the Chesapeake Bay [36] [38], where the relatively low values measured, despite a massive presence of toxic Pseudo-nitzschia demonstrated also in that area, was considered to be the result of both genetic and environmental factors (e.g. light and salinity). The highest relative levels of DA at the stations VTA, RMB and LTE were also measured in June, but earlier than the maximum record at RMC. Despite this homogeneity in the occurrence of the relative DA peak values, temporal distribution of DA production showed a degree of variability between northern and southern stations. In the north, particulate DA had a winter-spring occurrence, whereas a more diffuse presence throughout the year was detected at south of the mouth of Tiber. In addition, the concentration of domoic acid appeared to be influenced by river runoff and by the prevailing, northward, coastal current [39] with consequent higher availability of nutrients in the sites affected by the Tiber plume. River discharge and nutrient loading have been considered to influence Pseudo-nitzschia population development all over the world, but a direct association between DA fluxes and nutrients in nature definitely deserves further investigation [36] [38].

\section{Conclusion}

The data reported in this paper are first to result from the application of relatively simple, practical immunosensors for the monitoring domoic acid in microalgal natural populations of the Mediterranean basin. These sensors showed 
an operating range and detection limits that made them highly suitable for controls in the field. Thus, they represent an important alternative tool to assist monitoring of potentially harmful DA presence in the marine environment, although further development could contribute to reducing the gap between the HPLC and immunosensor results obtained in this study. In any case, the electrochemical immunosensors were previously developed for DA detection in mussels [22] and were here optimised and applied to detect DA directly in phytoplankton samples, with no matrix effect. Commercially available ELISA kits offer highly sensitive toxin determination in algal extracts and water [40] but our method has proved to be more rapid ( 1 vs. $2.5 \mathrm{~h}$ ), simpler and easy to perform, with good accuracy and reproducibility. Thus, this method has a high potential to be an effective screening analytical technique to "sense" DA directly in algal producers and to trace toxin transfer and magnification through the food chain in real time [41].

\section{Acknowledgements}

We dedicate this work to the memory of Patrizia Albertano who led the research carried out at the Laboratory of Biology of Algae. Dr. Simona Polizzano and Dr. Antonio Radoi are gratefully acknowledged for their help during domoic acid analyses; we also thank the team of the Regional Agency for Environmental Protection of Latium (ARPALazio), Department of Latina, for the sample collection. L. M. and G. P. also thank the EU Project SMS Ocean N. 2013-1 for the financial support.

\section{References}

[1] Hoagland, P. and Scatasta, S. (2006) Chap. 30. The Economic Effects of Harmful Algal Blooms. In: Granéli, E. and Turner, J., Eds., Ecology of Harmful Algae. Ecology Studies Series, Springer-Verlag, Dordrecht, 391-402. https://doi.org/10.1007/978-3-540-32210-8_30

[2] Morgan, K.L., Larkin, S.L. and Adams, C.M. (2009) Firm-Level Economic Effects of HABS: A Tool for Business Loss Assessment. Harmful Algae, 8, 212-218.

[3] Hallegraeff, G.M. (2003) Harmful Algal Blooms: A Global Overview. In: Hallegraeff, M., Anderson, D.M. and Cembella, A.D., Eds., Manual on Harmful Marine Microalgae. Monographs on Oceanographic Methodology, 2nd Edition, IOC-UNE-SCO, Paris, 25-49.

[4] Anderson, D.M. (2009) Approaches to Monitoring, Control and Management of Harmful Algal Blooms (HABs). Ocean \& Coastal Management, 52, 342-347.

[5] Anderson, D.M., Reguera, B., Pitcher, G.C. and Enevoldsen, H.O. (2010) The IOC International Harmful Algal Bloom Program: History and Science Impacts. Oceanography, 23, 72-85. https://doi.org/10.5670/oceanog.2010.25

[6] Anderson, D.M., Cembella, A.D. and Hallegraef, G.M. (2012) Progress in Understanding Harmful Algal Blooms: Paradigm Shifts and New Technologies for Research, Monitoring, and Management. Annual Review of Marine Science, 4, 143 176. https://doi.org/10.1146/annurev-marine-120308-081121

[7] Bates, S.S. and Trainer, V.L. (2006) The Ecology of Harmful Diatoms. In: Graneli, E. and Turne, J.T., Eds., Ecology of Harmful Algae, Ecological Studies, Springer-Ver- 
lag, Berlin, 81-93. https://doi.org/10.1007/978-3-540-32210-8_7

[8] Trainer, V.L., Bates, S.S., Lundholm, N., Thessen, A.E., Cochlan, W.P., Adams, N.G. and Trick, C.G. (2012) Pseudo-nitzschia Physiological Ecology, Phylogeny, Toxicity, Monitoring and Impacts on Ecosystem Health. Harmful Algae, 14, 271-300.

[9] Lefebvre, K.A. and Robertson, A. (2010) Domoic Acid and Human Exposure Risks: A Review. Toxicon, 56, 216-230.

[10] Caroppo, C., Congestri, R., Bracchini, L. and Albertano, P. (2005) On the Presence of Pseudo-nitzschia calliantha Lundholm, Moestrup et Hasle and Pseudo-nitzschia delicatissima (Cleve) Heiden in the Southern Adriatic Sea (Mediterranean Sea, Italy). Journal of Plant Research, 27, 763-774. https://doi.org/10.1093/plankt/fbi050

[11] Zingone, A., Siano, R., D’Alelio, D. and Sarno, D. (2006) Potentially Toxic and Harmful Microalgae from Coastal Waters of the Campania Region (Tyrrhenian Sea, Mediterranean Sea). Harmful Algae, 5, 321-337.

[12] Congestri, R., Polizzano, S. and Albertano, P. (2008) Toxic Pseudo-nitzschia Populations from the Middle Tyrrhenian Sea (Mediterranean Sea, Italy). In: Evangelista, V., Barsanti, L., Frassanito, A.M., Passatelli, V. and Gualtieri, P., Eds., Algal Toxins. Nature, Occurrence, Effect and Detection, Springer, Netherlands, NATO Science Series, Chemistry and Biology, 197-210.

[13] Cerino, F., Orsini, L., Sarno, D., Dell'Aversano, C., Tartaglione, L. and Zingone, A. (2005) The Alternation of Different Morphotypes in the Seasonal Cycle of the Toxic Diatom Pseudo-nitzschia galaxiae. Harmful Algae, 4, 33-48.

[14] Amato, A., Ludeking, A. and Kooistra, W.H.C.F. (2010) Intracellular Domoic Acid Production in Pseudo-nitzschia multistriata Isolated from the Gulf of Naples (Tyrrhenian Sea, Italy). Toxicon, 55, 157-161.

[15] Wright, J.L.C., Boyd, R.K., de Freitas, A.S.W., Falk, M., Foxall, R.A., Jamieson, W.D., Laycock, M.V., McCulloch, A.W., McInnes, A.G., Odense, P., Pathak, V., Quilliam, M.A., Ragan, M., Sim, P.G., Thibault, P., Walter, J.A., Gilgan, M., Richard, D.J.A. and Dewar, D. (1989) Identificationof Domoic Acid, a Neuroexcitatory Amino Acid, in Toxic Mussels from Eastern Prince Edward Island. Canadian Journal of Chemistry, 67, 481-490. https://doi.org/10.1139/v89-075

[16] Official Methods of Analysis of AOAC International. Official Method 206.02. In: Horwitz, W., Eds., Official Methods of Analysis of AOAC International, 19th Edition, Gaithersburg, MD.

[17] Quilliam, M.A. (2003) The Role of Chromatography in the Hunt for Red Tide Toxins. Journal of Chromatography A, 1000, 527-548.

[18] AOAC International (2000) AOAC Official Method 991.26 (2000). In: Horwitz, W., Official Methods of Analysis of AOAC International, AOAC International, Gaithersburg, Maryland.

[19] Quilliam, M.A. (2003) Chemical Methods for Domoic Acid, the Amnesic Shellfish Poisoning (ASP) Toxin. In: Hallegraeff, M., Anderson, D.M. and Cembella, A.D., Eds., Manual on Harmful Marine Microalgae, Monographs on Oceanography Methodology Intergovernmental Oceanographic Commission, UNESCO, Paris, 247266.

[20] Wang, Z., King, K.L., Ramsdell, J.S. and Doucette, G.J. (2007) Determination of Domoic Acid in Seawater and Phytoplankton by Liquid Chromatography-Tandem Mass Spectrometry. Journal of Chromatography A, 1163, 169-176.

[21] Dahlmann, J., Budakowski, W.R. and Lucka, B. (2003) Liquid ChromatographyElectrospray Ionisation-Mass Spectrometry Based Method for the Simultaneous Determination of Algal and Cyanobacterial Toxins in Phytoplankton from Marine Waters and Lakes Followed by Tentative Structural Elucidation of Microcystins. 
Journal of Chromatography $A$, 994, 45-57.

[22] Micheli, L., Radoi, A., Guarrina, R., Massaud, R., Bala, C., Moscone, D. and Palleschi, G. (2004) Disposable Immunosensor for the Determination of Domoic Acid in Shellfish. Biosensors \& Bioelectronics, 20, 190-196.

[23] Volpe, G., Fares, G., Draisci, R., Ferretti, G., Marchiafava, C., Moscone, D. and Palleschi, G. (2003) A Disposable Immunosensor for Detection of $17 \beta$-Estradiol in Non-Extracted Bovine Serum. Analytica Chimica Acta, 572, 11-16.

[24] Ricci, F., Volpe, G., Micheli, L. and Palleschi, G. (2007) A Review on Novel Developments and Applications of Immunosensors in Food Analysis. Analytica Chimica Acta, 605, 111-119.

[25] Ammida, N.H.S., Micheli, L. and Palleschi, G. (2004) Electrochemical Immunosensor for Determination of Aflatoxin $\mathrm{B}_{1}$ in Barley. Analytica Chimica Acta, 520, 159 164.

[26] Piermarini, S., Volpe, G., Ricci, F., Micheli, L., Moscone, D., Palleschi, G. and Führer, M. (2007) Rapid Screening Electrochemical Methods for Aflatoxin $B_{1}$ and Type-A Trichothecenes: A Preliminary Study. Analytical Letters, 40, 1333-1346. https://doi.org/10.1080/00032710701326692

[27] Arduini, F., Amine, A., Moscone, D., Ricci, F. and Palleschi, G. (2007) Fast, Sensitive and Cost-Effective Detection of Nerve Agents in the Gas Phase Using a Portable Instrument and an Electrochemical Biosensor. Analytical and Bioanalytical Chemistry, 388, 1049-1057. https://doi.org/10.1007/s00216-007-1330-Z

[28] Jiang, X., Li, D., Xu, X., Yin, Y., Li, Y., Ye, Z. and Wang, J. (2008) Immunosensors for Detection of Pesticide Residues. Biosensors \& Bioelectronics, 23, 1577-1587.

[29] Mahosenaho, M., Caprio, F., Micheli, L., Sesay, A.M., Palleschi, G. and Virtanen, V. (2010) A Disposable Biosensor for the Determination of Alpha-Amylase in Human Saliva. Microchimica Acta, 170, 243-249. https://doi.org/10.1007/s00604-010-0360-y

[30] Canadian Food Inspection Agency (1999) Domoic Acid Extraction and Analysis Procedure. Fish, Seafood and Production, Chemical Methods Manual. www.inspection.gc.ca

[31] Bates, S.S., de Freitas, A.S.W., Milley, J.E., Pocklington, R., Quilliam, M.A., Smith, J.C. and Worms, J. (1991) Controls on Domoic Acid Production by the Diatom Nitzschia pungens $\mathrm{f}$. multiseries in Culture: Nutrients and Irradiance. Canadian Journal of Fisheries and Aquatic Science, 48, 1136-1144. https://doi.org/10.1139/f91-137

[32] Warwick, M.J. (1996) Immunoassay, A Practical Guide. Taylor \& Francis Ltd., London.

[33] Ciminiello, P., Dell'Aversano, C., Fattorusso, E, Forino, M., Magno, S., Santelia, F. and Tsoukatou, M. (2006) Investigation of the Toxin Profile of Greek Mussels Mytilus galloprovincialis by Liquid Chromatography-Mass Spectrometry. Toxicon, 47, 174-181.

[34] Marić, D., Ljubešić, Z., Godrijan, J., Viličić, D., Ivana, I., Ujević, I. and Precali, R. (2011) Blooms of the Potentially Toxic Diatom Pseudo-nitzschia calliantha Lundholm, Moestrup \& Hasle in Coastal Waters of the Northern Adriatic Sea (Croatia). Estuarine, Costal and Shelf Science, 92, 323-331.

[35] Busse, L.B., Venrick, E.L., Antrobus, R., Miller, P.E., Vigilant, V., Silver, M.W., Mengelt, C., Mydlarz, L. and Prezelin, B.B. (2006) Domoic Acid in Phytoplankton and Fish in San Diego, CA, USA. Harmful Algae, 5, 91-101.

[36] Schnetzer, A., Miller, P.E., Schaffner, R.A., Stauffer, B.A., Jones, B.H., Weisberg, 
S.B., DiGiacomo, P.M., Berelson, W.M. and Caron, D.A. (2007) Blooms of Pseudonitzschia and Domoic Acid in the San Pedro Channel and Los Angeles Harbor Areas of the Southern California Bight, 2003-2004. Harmful Algae, 6, 372-387.

[37] Klein, C., Claquin, P., Bouchart, V., Le Roy, B. and Véron, B. (2010) Dynamics of Pseudo-nitzschia spp. and Domoic Acid Production in a Macrotidal Ecosystem of the Eastern English Channel (Normandy, France). Harmful Algae, 9, 218-226.

[38] Thessen, A.E. and Stoecker, D.K. (2008) Distribution, Abundance and Domoic Acid Analysis of the Toxic Diatom Genus Pseudo-nitzschia from the Chesapeake Bay. Estuaries and Coasts, 31, 664-672. https://doi.org/10.1007/s12237-008-9053-8

[39] Artale, V., Astraldi, M., Buffoni, G. and Gasparini, G.P. (1994) Seasonal Variability of Gyre-Scale Circulation in the Northern Tyrrhenian Sea. Journal of Geophysical Research, 99, 14127-14137. https://doi.org/10.1029/94JC00284

[40] Kleivdal, H., Kristiansen, S.I., Nilsen, M.V. and Briggs, L. (2007) Single-Laboratory Validation of Biosense Direct Competitative Enzyme-Linked Immunosorbent Assay (ELISA) for the Determination of Domoic Acid Toxins in Shellfish. Journal of AOAC International, 90, 1000-1010.

[41] Albertano, P., Congestri, R., Micheli, L., Moscone, D. and Palleschi, G. (2008) Development of Sensors to Trace Toxins from Dinoflagellates and Other Algae to Seafood. In: Evangelista, V., Barsanti, L., Frassanito, A.M., Passarelli, V. and Gualtieri, P., Eds., Algal Toxins: Nature, Occurrence, Effect and Detection, NATO Science for Peace and Security Series A: Chemistry and Biology, Springer, Dordrecht, 301-310. https://doi.org/10.1007/978-1-4020-8480-5_14

\section{Submit or recommend next manuscript to SCIRP and we will provide best service for you:}

Accepting pre-submission inquiries through Email, Facebook, LinkedIn, Twitter, etc. A wide selection of journals (inclusive of 9 subjects, more than 200 journals)

Providing 24-hour high-quality service

User-friendly online submission system

Fair and swift peer-review system

Efficient typesetting and proofreading procedure

Display of the result of downloads and visits, as well as the number of cited articles

Maximum dissemination of your research work

Submit your manuscript at: http://papersubmission.scirp.org/

Or contact ajps@scirp.org 